\title{
Development of Rural Areas and Improving Their Resilience with Smart Solutions
}

\author{
PÉTER ZSOLT, Ph.D. \\ ASSOCIATE PROFESSOR \\ UNIVERSITY OF MISKOLC \\ e-mail: regpzs@uni-miskolc.hu
}

\begin{abstract}
SUMMARY
Rural development is increasingly demanding the use of advanced technologies as a growing number of new challenges must be solved. While the main tasks in cities are to develop the quality of life of a significant number of people and to solve increasingly complicated tasks, in rural areas - in many cases - aging, the migration of the youth and the more difficult access to services (and in many cases their higher costs) are the most important problems.

Basic IT infrastructures are usually available in the most rural areas (e.g. broadband Internet access), and the cost of Internet-connected devices has fallen compared with decades ago, so in theory it is easy to access for everyone, but the existence of 'hardware' is sometimes accompanied by a lack of necessary 'software'. I believe that one of the potential opportunities of rural areas can be the widespread use of smart solutions developed by densely populated areas but adaptable with inevitable modifications. In this study first I will examine the current situation of the 'smart solutions' in rural places and then I will discuss how such solutions can contribute to the development and resilience of rural areas. Keywords: smart cities, smart rural areas, rural development, territorial differences, resilience
\end{abstract} Journal of Economic Literature (JEL) code: R11

DOI: http://dx.doi.org/10.18096/TMP.2020.01.04

\section{INTRODUCTION}

Spatial development can no longer ignore the use of advanced technologies. While in urban areas the management of the masses in different areas is one of the most common problems (transport, administration, health services, education, etc.), in rural areas the aging society and the decrease of available services and jobs are the biggest challenges. In this study I am looking for an answer as to whether ICT tools, mobile and computer applications can make a significant contribution to mitigating and preventing the sometimes shocking effects on the economy, the environment and society. First I will review the national and international literature on smart solutions and resilience and then I will identify their meeting points with smart settlement and rural models. I will also collect a few best practices of 'smart' developments in rural areas that are making a significant contribution to improving their resilience.

\section{LITERATURE REVIEW - SMART CITIES}

The smart city concept appeared in the literature in the 1980s and became widespread in the '90s thanks to the use of information and communication technologies (ICT). In the 2000s, the increasing use of the Internet has helped the cities to provide more and more IT services to their citizens (e-governance, e-education, etc.), while today the revolution of the Internet of Things is going on.

While we use the term 'smart city' more and more often, no uniform concept has been developed yet in the literature, as there are often unique solutions for each settlement. Many definitions of smart city have been created in recent years, but there is no one-size-fits-all definition. Some definitions say that

$>$ a smart city excels in six areas: economy, people, governance, mobility, environment, living conditions (Giffinger 2007),

> the concept of the smart city is a place where citizens, objects, utilities, etc. are perfectly combined with the use of everyday technologies that significantly improve the urban experience (Northstream 2010), 
a smart city is a product of the combination of the digital city and the Internet of Things ( $\mathrm{Su} \& \mathrm{Li} \& \mathrm{Fu}$, 2011),

a smart city monitors and integrates all critical infrastructures (roads, bridges, tunnels, railways, subways, airports, ports, communications, water, energy, and major buildings), optimizing its resources, planning activities with safety in mind, maximizing the services provided to the population (Hall, 2000).

$>$ the concept of smart villages is encouraged by the promotion of economic and social development, sustainable energy, health, education, water and hygiene infrastructures, leading the places to increased incomes, improved security, greater gender equality and democratic values (Holmes, 2017).

One of the most important tools of these intelligent approaches is digitization, no matter whether urban or rural. Especially in rural areas, better internet access can help in decreasing distances between settlements and solve logistical, mobility and care problems for elderly or healthcare (Prause \& Boevsky, 2015).

In recent years, many similar names have appeared in the case of villages, such as 'smart village', 'intelligent village', 'knowledge village', 'sustainable village', 'talented village', 'wired village', ‘digital village'. I supposed that 'smart village' is the most popular expression but I have found that other expressions as 'knowledge and sustainable villages' are more widely used.

\section{LITERATURE REVIEW - RESILIENCE AND ITS CONNECTION WITH RURAL AREAS}

I have reviewed the concept of resilience, its appearance and its use in different sciences, with special regard to economics in the Hungarian and international literature.

The concept of resilience first appeared in 1973 in relation to the resilience of ecosystems. Recently it has become an extremely fashionable scientific expression, which is almost universal in describing systems and solving problems (Gardner \& Dekens 2007).

Resilience - which in a time of shock ensures functional survival - has become a hot research topic in many scientific disciplines, particularly ecology and psychology. In the context of socio-economic 'sustainability', resilience is particularly concerned with adapting to climate change and the survival of disasteraffected communities (Bahadur et al., 2010). Holling's approach seems also logical to me, as he says that after shocks resilient systems will return to equilibrium, whether it is different or not from the original state (Holling, 2001)

Table 1

The mention of "Smart Village" and similar terms in Internet search engines

\begin{tabular}{|c|c|c|c|c|}
\hline EN & google EN & $\%$ & $\begin{array}{l}\text { google } \\
\text { scholar }\end{array}$ & $\%$ \\
\hline 'smart village' & 383000000 & 11.00 & 347000 & 3.87 \\
\hline $\begin{array}{l}\text { 'intelligent } \\
\text { village' }\end{array}$ & 61700000 & 1.77 & 458000 & 5.11 \\
\hline $\begin{array}{l}\text { 'knowledge } \\
\text { village' }\end{array}$ & 458000000 & 13.15 & 3120000 & 34.80 \\
\hline $\begin{array}{c}\text { 'sustainable } \\
\text { village' }\end{array}$ & 147000000 & 4.22 & 1100000 & 12.27 \\
\hline $\begin{array}{l}\text { 'talented } \\
\text { village' }\end{array}$ & 74500000 & 2.14 & 169000 & 1.89 \\
\hline 'wired village' & 26700000 & 0.77 & 72400 & 0.81 \\
\hline $\begin{array}{l}\text { 'digital } \\
\text { village' }\end{array}$ & 712000000 & 20.44 & 498000 & 5.56 \\
\hline $\begin{array}{l}\text { 'information } \\
\text { village' }\end{array}$ & 1620000000 & 46.51 & 3200000 & 35.70 \\
\hline sum & 3482900000 & 100.00 & 8964400 & 100.00 \\
\hline
\end{tabular}

Source: own compliation 


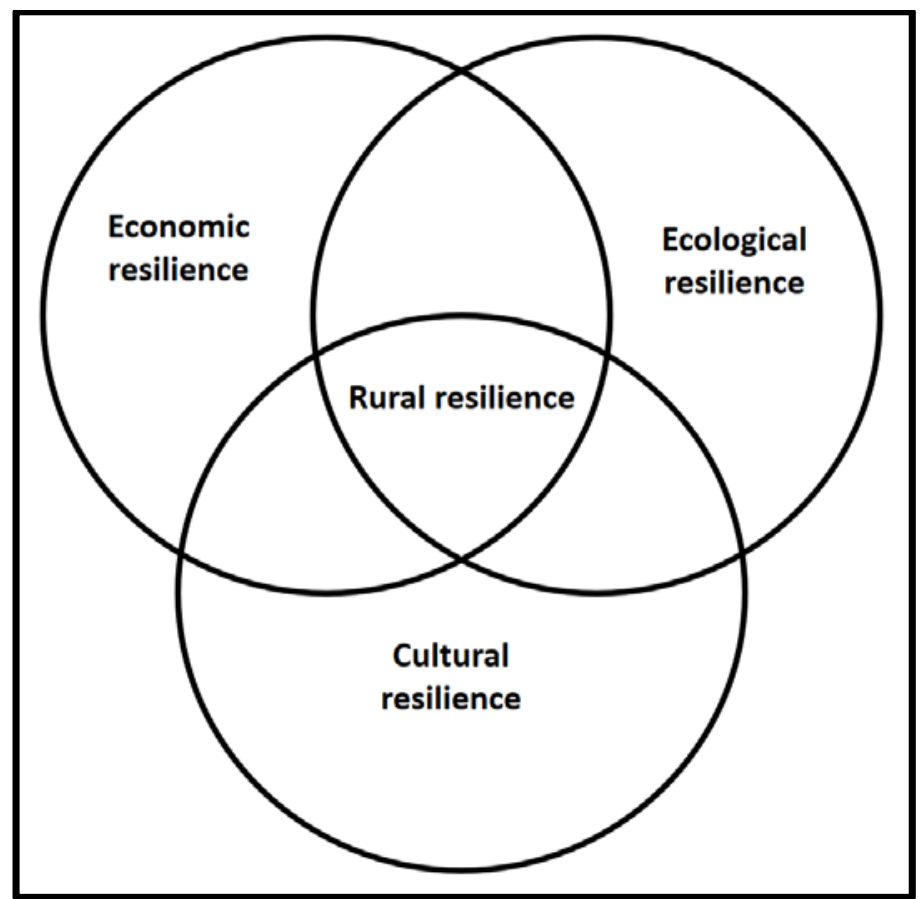

Source: Heijman et al. 2019

Figure 1. Components of rural resilience

Only a few examples of the relationship between the concept of resilience and the countryside can be found in the literature. This is probably because rural areas typically lack the resources needed to mitigate and prevent shock effects. Some sources suggest that this is because the majority of researchers currently focus directly on rapid changes in agriculture, forestry, landscape protection or social problems (Colding, 2007; CSIRO, 2007).

Only some authors try to circumvent the definition of this relationship. The resilience of the rural areas is the ability of the countryside to maintain an acceptable standard of living for the members of the community despite the rapidly changing external conditions. Figure 1 shows that the resilience of rural areas can be quite well defined as some common intersection or combination of the resilience of certain areas (especially economic, ecological, and cultural) (Heijman et al. 2019).

During the examination of the phenomenon of resilience, it should be borne in mind that rural areas have several functions at the same time. While agriculture is feeding humans and animals, at the same time it serves other areas (tourism, cultural heritage, and the conservation of water, landscape and nature). Occasionally resources may be limited, e.g. taking into account natural values or food safety considerations. Another multifunctional approach incorporates the concept of economic, social and natural capital to model rural resilience issues (Wilson, 2010). 


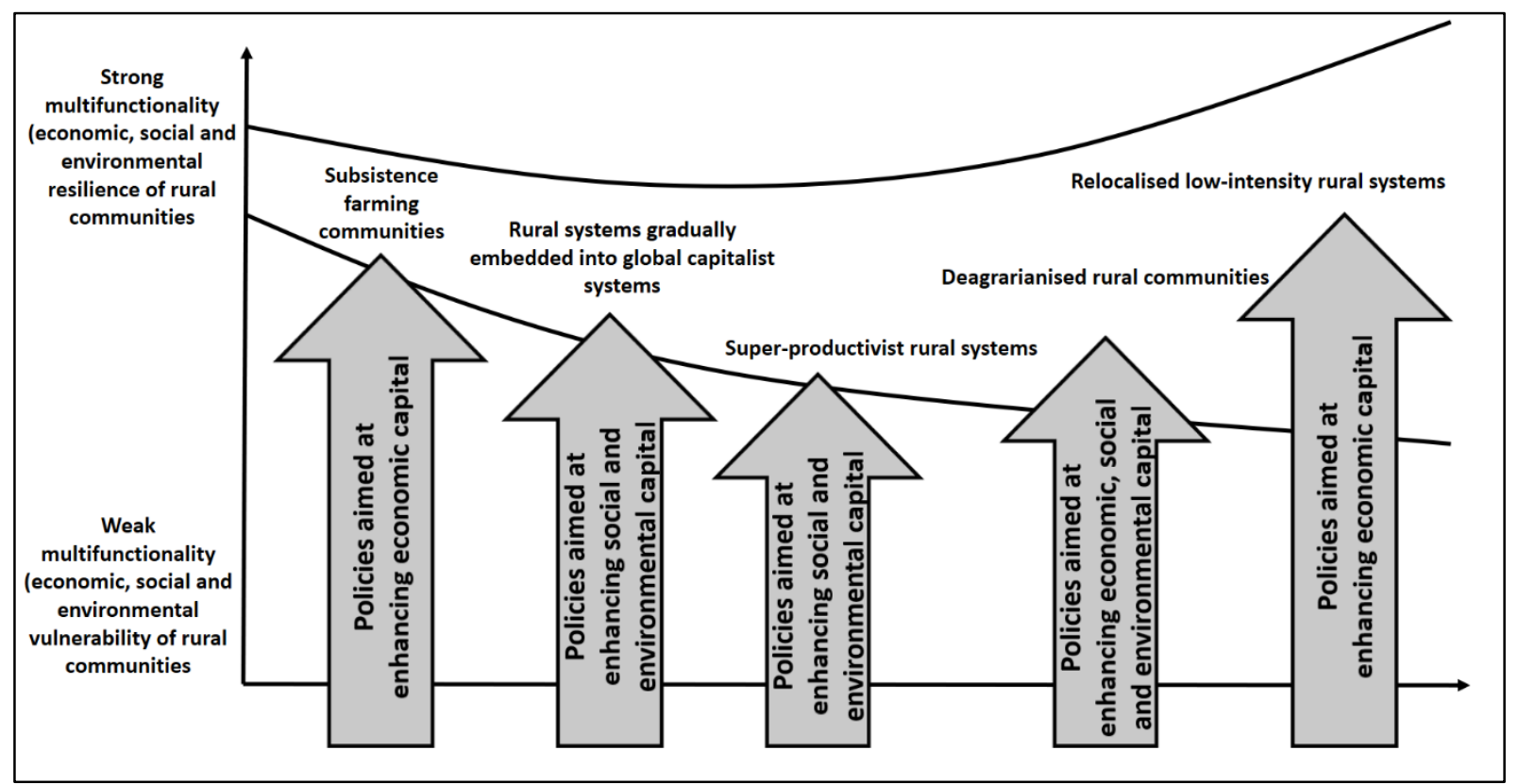

Source: Wilson, 2010

Figure 2. The relationship between the possible development paths of rural areas and the main goals of rural policy

Rural areas were historically self-sufficient, although such areas still exist in distant areas. Thanks to the industrial revolution and the advent of modern societies, rural areas are also taking part in the economy of global capitalism. Some rural areas are highly capable of increasing the efficiency of certain agricultural activities (e.g. the greenhouses of Almería, Spain), enabling them to become market leader or dominant players on a global scale for certain products or product groups.

Less favorable conditions or the proximity of larger cities leads certain areas to reduce agricultural activity while at the same time ideally they can expand industrial or service activities. Some rural areas of developed economies, especially those close to big cities, have undergone a change of function over the last decade, providing comfortable living conditions, decent work opportunities, and many functions similar to cities in many areas (e.g. services, shopping). Typically, areas remote from large cities are characterized by low agricultural productivity, which can only bring benefits if it is of high quality and at the same time, it is coupled with high prices accepted by the market, otherwise it can be sustainable only with a certain degree of foreclosure or with significant external funding. Wilson's approach (Figure 2) also incorporates the decision-making dimension of the different development pathways (Wilson, 2010).

Increasing economic capital is a priority for selfsufficient rural areas. They should reduce the number of people living in poverty, improve living standards, diversify the economy, reduce dependence on agriculture, develop infrastructure and increase the volume of products sold in the region.

Slowly integrating rural areas into the global economy should improve their culture of cooperation, improve health and social care, improve the quality of services and encourage women's economic empowerment.

Highly productive rural/agricultural areas identify most of the abovementioned objectives for themselves. However, in their case, over-specialization can entail serious dangers (e.g. ecological risks, environmental pressures, major landscape changes). 


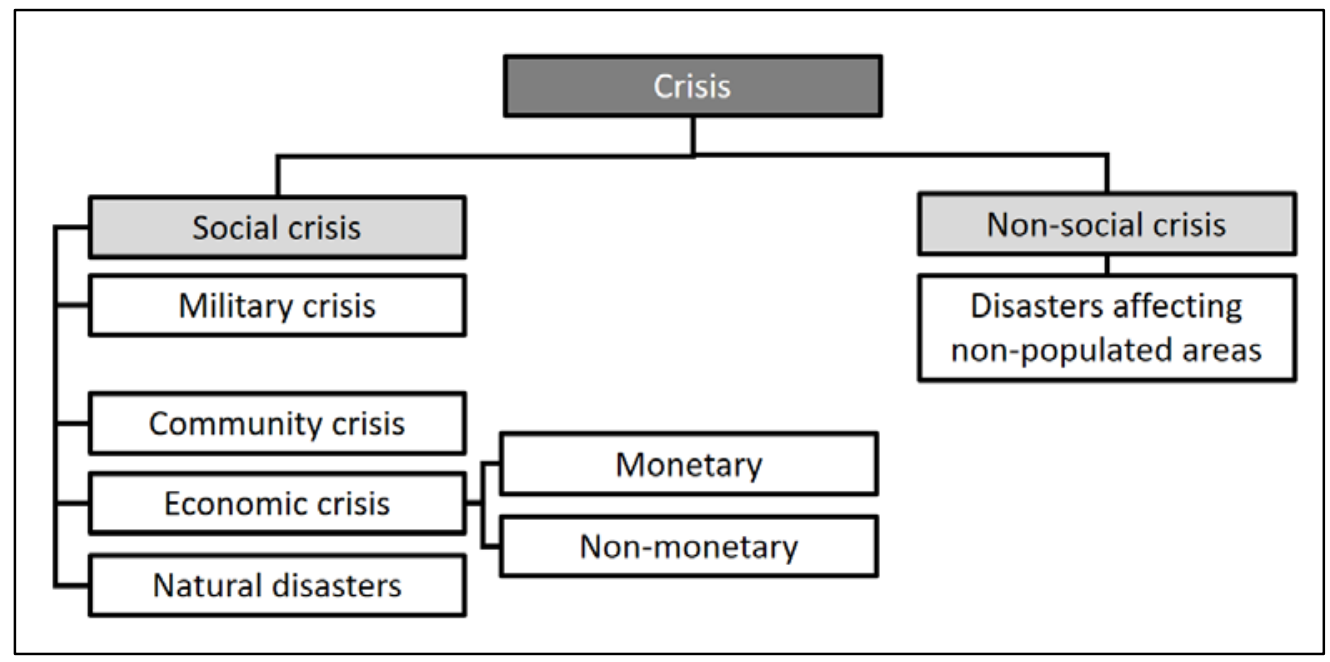

Source: own compilation

Figure 3. The typology of crises

In rural areas, which are typically located around urban areas, agriculture is losing ground, which may be due to competitive disadvantages and the expected higher income from non-agricultural land use. In areas of the country where productivity is lower than expected levels of production, the issue of increasing and preserving economic capital may once again be at the center of development policy; as population decline, the expected increase in absolute and relative poverty, external dependence and outflows are key challenges (Szendi, 2017).

When examining the resilience of rural areas, we cannot ignore the literature on crisis, crisis prevention, crisis management and management (Boin et al., 2005). A crisis is a situation in which society is affected by some significant adverse physical, economic or community negative effects. In the event of a crisis, it is the responsibility of the crisis management organization to make decisions, often in very difficult circumstances or with potentially adverse consequences for certain groups in society (Sayegh et al., 2004). A crisis is a disorder of a system characterized by some degree of insecurity and discontinuity, and requires special treatment to avoid unwanted consequences and to establish a new stable state (Bénaben \& Frédérick, 2016).

Crises often occur unexpectedly and decision-makers are confronted with the fact that information often unreliable from previous crises will not help solve current problems. In many cases, the involvement of external consultants in crisis management is also required.

As a result of the 2008 crisis, resistance studies have also come to the forefront in rural areas.

There have been developed many specialized literature dealing with crisis and crisis management, but an overall typology of crises can be difficult to find covering all possible areas. Crises can be societal or non-societal (e.g. natural disasters affecting wildlife in uninhabited places). Crises with a major impact on society can also come from natural sources. Since armed conflicts are fortunately less common in developed countries (from internal or external sources), many authors refuse to include them as causes. In my opinion, this is a poor choice, as it damages the completeness of the possible causes (and unfortunately, there are still armed conflicts in many parts of the world). The third important group of crises is economic, due to financial or other reasons (Figure 3).

Based on an overview of crisis concepts, I have come to the conclusion that resilience, which is becoming more and more popular as a research topic today, deals with many similar issues. Perhaps the most significant difference is that while crisis management focuses primarily on mitigating and managing the negative effects, resilience is not exclusively concerned with unfavorable factors but focuses more on the development of equilibrium at the same or possibly different levels.

In this study I would like to propose the main areas of smart solutions for rural areas. We can review and the 'smart improvements' that are already available, draw conclusions based on previous experience, and make predictions by the help of the ideas currently under development. There is only limited scope for this activity due to the fragmentation of the information available.

In this research, although we cannot speak for completeness or representativeness in the case of Hungary, we can come to the conclusion that most of the domestic developments were made from EU sources, without real 'business' or long-term economic 'sustainability' planning. Many times, IT developments are made that do not have 'real' users. Quite often similar domestic or even global alternatives already exist (for example, I find it unnecessary to develop a tourist application for a village when Google Maps or Tripadvisor, for example, provide a much more efficient service for the same purpose).

To precisely define the areas to be developed, the tasks and goals of the rural areas can help us. 
In my opinion a globally applicable classification is needed. The horizontal axis shows the economic development of the rural area (country). The vertical axis shows the distance from important economic centers (big cities). According to the two dimensions (although these are, of course, not discrete categories), four groups are created:

$>$ areas close to a (large) city (or cities) of developed countries,

$>$ peripheral rural areas of developed countries,

$>$ areas close to a (large) city (or cities) of underdeveloped countries,

$>$ peripheral rural areas of underdeveloped countries.

Giffinger's model is the most widely used in the literature and is commonly used to determine the development areas of smart solutions (Giffinger 2007). People living in rural areas near urban areas in developed countries tend to have similar lifestyles to urban populations, and agriculture in these areas is no longer dominant even if they have gained extraordinary productivity in some areas (e.g. vegetable production), since alternative land use income can easily be higher. The keywords in these areas are: development, further development, optimization with particular emphasis on the following areas (innovation, businesses environment, productivity, international relations, competitiveness, NGOs, e-government interfaces, community, social services, public transport, health services, improvement of public security, energetics).

The technology available can help projects to improve the natural environment. Often it can be a problem that significant tourist values fade in the shadow of the nearby big cities, so it is important to increase domestic and international visibility and achieve the necessary market positioning (Kuttor, 2008).

The remote peripheral areas of developed countries (e.g. near the Arctic Circle in northern countries) face quite different challenges. In these places, the focus should be on creating an innovation environment, attracting businesses to the area, stimulating atypical forms of employment, and branding the area to attract foreign tourists.

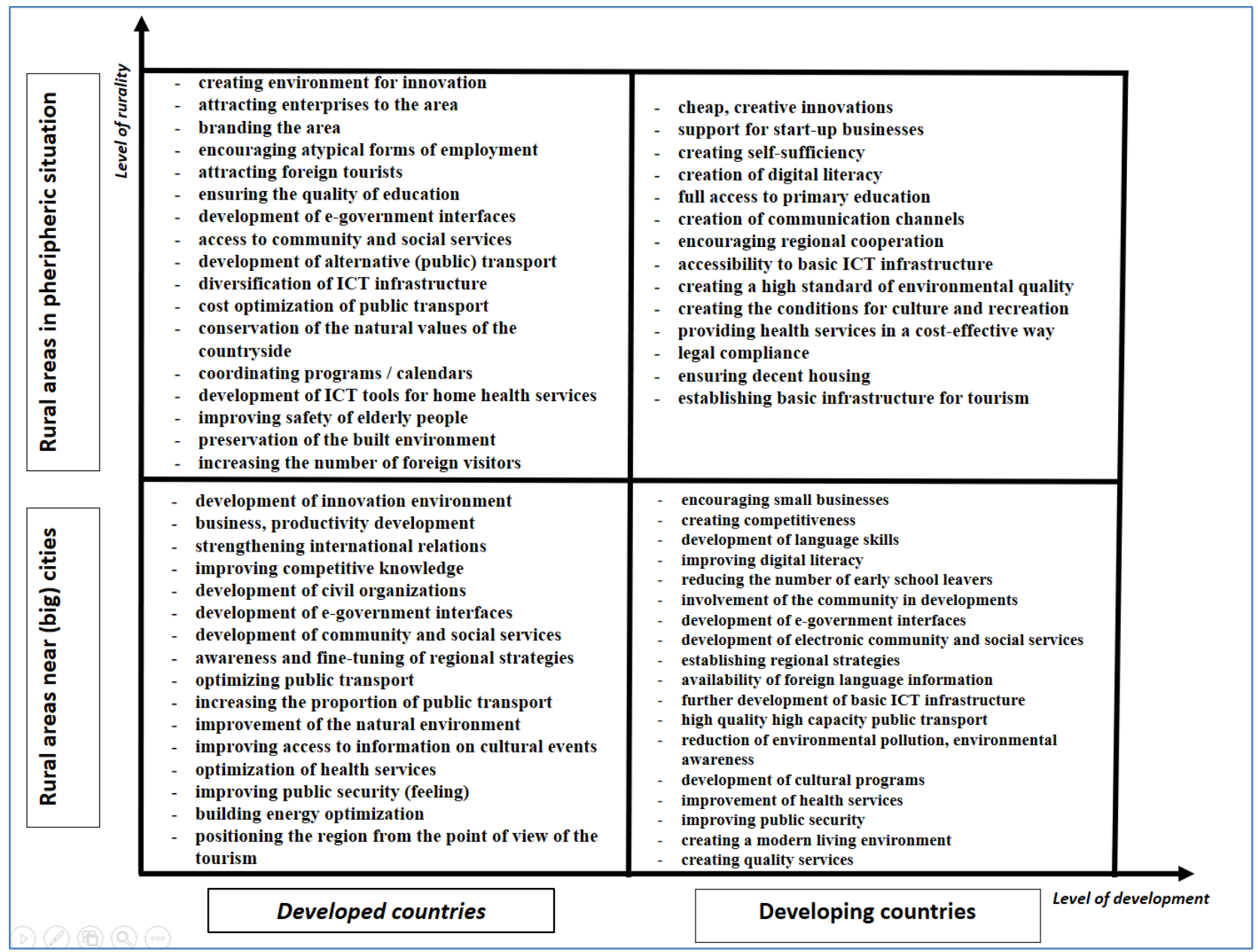

Source: own compilation based on Giffinger’s model (Giffinger 2007)

Figure 4. The main development areas for smart solutions in regions depending on their countries' level of development and level of rurality 
If the low population density requires distance education techniques, ensuring the quality of education can be challenging. E-government interfaces are often inadequate, and the community and social services may require special IT-supported solutions, especially because of the high costs per capita of the traditional solutions. In my opinion, the main focus points could be the development of alternative (community) transport, the cost optimization of public transport, the preservation of the natural values of the countryside, the coordination of community programs and calendars, the development of home health ICT tools, and the safety of the elderly..

Often massive population growth can be observed near major cities in developing countries as part of strong urbanization processes. In these areas, we can use smart tools to encourage small businesses, improve competitiveness, develop foreign language skills, improve digital literacy and reduce the number of early school leavers. It is important to involve the community members in the development process. The development of egovernment interfaces and electronic community-based social services can reduce congestion. Access to foreign language information is a typical shortcoming. Breakthrough points could be the further development of basic ICT infrastructure and the development of highquality, high-capacity public transport (metro, high-speed rail, metro, tram, etc.). Pollution is a major problem, and reducing it can help to improve life expectancy and quality. The development of cultural programs, the improvement of health services, public security, the creation of a modern living environment, and the creation of high quality services may be the main areas of development.

In the peripheral areas of underdeveloped countries, cost effectiveness and creativity must be the hallmarks of development. It is important that under-educated people be able to use the applications, too. It is interesting that some forced innovations (such as payment without a bank account) were first created in poor countries. The keywords in this rural group are support and creation. We need to help start-up businesses with IT or other 'smart' tools, to ensure the self-sufficiency of the population, and we have to make the Internet available for everybody: we have to help creating digital literacy, full access to primary education, and basic communication channels. Regional co-operation should be encouraged and the quality of environment and environment consciousness should be improved. In these areas, it is necessary to create the conditions for culture and recreation, to provide costeffective health services and decent housing, and to establish the basic infrastructure for tourism (Figure 4).

\section{THE ROLE OF SMART SOLUTIONS IN IMPROVING RESILIENCE IN RURAL AREAS - CASE STUDIES}

During the process of gathering smart solutions in rural areas, we will face the fact that the information available is very fragmented. While in Hungary, the Lechner Knowledge Center operates a website (http://okosvaros.lechnerkozpont.hu) that collects smart solutions from Hungary and European countries, with special regard to urban development, I was unable to found a collection of smart solutions specifically developed in rural areas. Sites for smart solutions typically exist in some major cities (e.g. Amsterdam).

Due to information gaps, I would like to outline some good practices that can provide guidance for other rural communities.

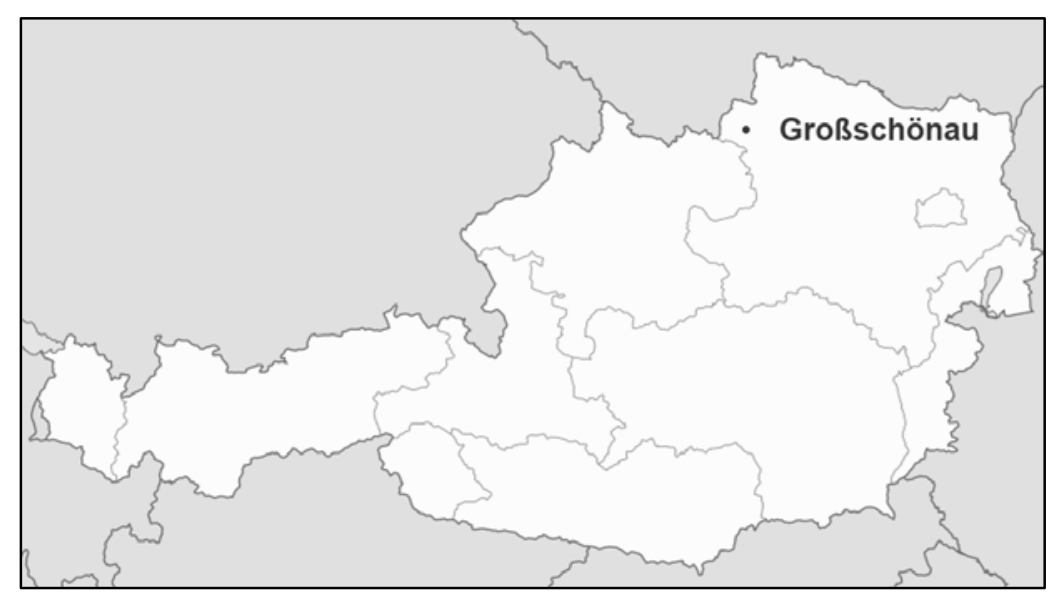

Source: google.com

Figure 5. Location of Großschönau, Austria 
First I would like to introduce the developments of the small Austrian settlement of Großschönau, with around 1,200 inhabitants, located at a distance of $30 \mathrm{~km}$ from the Czech border (Figure 5). In this village smart solutions were launched with the help of 'smart' people many years before the concept became widespread. In the 1980s, the mayor and his brother (headmaster of the school) were confronted with the fact that the population of their settlement was decreasing and their room for maneuver was slowly but surely diminishing. With the involvement of the locals, they reconsidered their situation and concluded that they needed to become a settlement that could offer competitive, low-cost but excellent quality of services to the population, potential settlers and tourists. The developments were concentrated in the field of energetics. When the heating system of the school needed to be modernized the mayor of the village convinced locals to join the newly developed district heating system, which can save significant costs. Step by step the buildings of the municipality and the residences have been modernized, with special regard to their insulation. In a new part of the settlement, passive houses have been built, which have been sold and also serve as a model for those interested in their architecture and design. An interactive exhibition site called 'Sonnenwelt' was built in the town, with the aim of promoting energy consciousness. The museum of the settlement receives more than one hundred thousands of visitors each year, generating significant revenue for the municipality. The building functions not only as an exhibition space. There are also conference rooms and rooms suitable for indoor activities. They recently have hosted one hundred programs each year, which are provided to the local population and visitors. All this significantly boosted the turnover of hosts and other tourism service providers.

The municipality has implemented a number of developments (e.g. sewage treatment plants) which use the workforce in a very efficient way and also provide profitoriented services to other municipalities. These revenues contribute to the implementation of new developments. The attitude of the population has also changed in recent decades, which is embodied in private initiatives launched without the participation of the municipality (e.g. local district heating systems in the peripheral parts of the settlement).

Due to complex, consistent developments, the resilience of the settlement has increased significantly. The dependence on the outside world has significantly decreased in the area of food supply thanks to the quality and variety of services offered.

Another example is ReGen Village, which is located in the Netherlands, approx. $20 \mathrm{~km}$ from Almere and is still under construction. The essence of this project is to make the village completely self-sufficient. The concept is to develop a village where resources are used in a closed system. This means that waste and water recycling, food production and energy production in the village is done in a way that minimizes the burden on the environment and serves all household needs, and the excess is redistributed to households (https://iut.univ-amu.fr/).

The ReGen Village project is based on five pillars:

$>$ water and waste recycling,

$>$ high-yield organic food production,

$>$ multi-source renewable energy production and storage,

$>$ buildings with a positive energy balance,

$>$ strengthening local communities.

The resilience is clearly high for such a fully selfsufficient settlement, but some fears have been identified during the design process:

$>$ although the Netherlands is a rainy country, rainwater may not be sufficient to meet the full needs of the population,

$>$ high costs may result in an over-concentration of highincome owners,

$>$ since the village is $100 \%$ self-sufficient, a kind of sense of isolation may occur,

$>$ while the project focuses entirely on meeting basic needs (food production, housing), it may not provide enough entertainment for its residents,

$>$ it can also be a problem that the houses are too close to each other and do not give their residents adequate intimacy (www.iut.univ-amu.fr).

As mentioned above, in the peripheral areas of underdeveloped countries, affordability and creativity must be the main drivers of development. It is important that non-skilled people can use the newly developed applications. A very good example of this is the Rwandan development called TRACnet, which connects residents and health facilities through an online platform. Physicians in peripheral areas of the country will have access to any previous medical report within a few seconds, and the system will tell them what and how many medications they need. This solution was created primarily to reduce HIV infection (https://sustainabledevelopment.un.org).

Rimbunan Kaseh in Malaysia is a 30-hectare rural village near Kuala Lumpur, which can serve as a good example of addressing rural poverty by promoting environmental sustainability through technology. A closed agricultural system is the greatest asset of the community, providing food and income to the population. In this system, everything is connected to everything. It also has everything like an usual settlement, schools, playgrounds, workplaces, and even 4G internet, while eHealth and eLearning work parallel in the community (Holmes, 2017).

\section{CONCLUSION}

Beyond the topic of energy networks the term 'Smart Rural Areas or Regions' and their synonyms are rarely found in the literature. Most of the sources deal with smart settlements (cities, villages).

During my research I have realized that there must be significant differences in terms of the tasks to be performed and the tools available, depending on how a 
rural area and its country developed and how peripheral its position is.

I concluded that Giffinger's model of a 'smart city', though with significant rethinking, can provide an appropriate framework for the tasks, goals and objectives that can be achieved through the use of smart ICT tools (Nagy et al. 2016).

I have created a model for the main development areas for smart solutions in regions depending on their countries' level of development and level of rurality based on Giffinger's findings.

I have collected a few good examples of smart concepts of rural areas. I found that the good and sustainable examples are almost never based on mainly on European
Union funds but on the real needs of the communities and their will to work for them. Based on my experience, I can state that the majority of local governments' projects in many countries are implemented mainly through European funds. Their sustainability after the expiry of the contractual obligations is usually doubtful. Thanks to the 'easy money', sustainability issues are very rarely included in the design of the projects. Often smart applications are not commensurate with the size of the settlements, and often focus on developments that already exist at national or global level. Sometimes the developed applications are already available from free or very affordable sources from already existing service providers (Szlávik et al. 2016; Orosz \& Péter 2018; Péter \& Orosz 2019;).

\section{Acknowledgement}

This research was supported by the project nr. EFOP-3.6.2-16-2017-00007, titled Aspects on the development of intelligent, sustainable and inclusive society: social, technological, innovation networks in employment and digital economy. The project has been supported by the European Union, co-financed by the European Social Fund and the budget of Hungary.

\section{REFERENCES}

BAHADUR A.V., \& IBRAHUM M. \& TANNER T. 2010: The resilience renaissance? Institute of Development Resilience, Brighton, UK..

BÉNABEN F. 2016: A Formal Framework for Crisis Management Describing Information Flows and Functional Structure. Procedia Engineering 159, 353-356. https://doi.org/10.1016/j.proeng.2016.08.208

BOIN A., \& HART, P., \& STERN, E., \& BOIN, B., S. 2005: The Politics of Crisis Management: Public Leadership under Pressure, Cambridge: Cambridge University Press-

COLDING, J. 2007: ‘Ecological land-use complementation’ for building resilience in urban ecosystems. Landscape and Urban Planning, 81 (1-2), 46-55. https://doi.org/10.1016/j.landurbplan.2006.10.016

CSIRO 2007: Research Prospectus for Urban Resilience; Resilience Alliance Initiative for Transitioning Urban Systems towards Sustainable Futures. Canberra, CSIRO.

GARDNER, J. \& DEKENS, J. 2007. Mountain hazards and the resilience of social-ecological systems: lessons learned in India and Canada. Natural Hazards, 41 (2), 317-336. https://doi.org/10.1007/s11069-006-9038-5

GIFFINGER R. 2007: Smart cities. Ranking of European medium-sized cities. Vienna: University of Technology

HALL, R., E. 2000: The vision of a smart city. In Proceedings of the 2nd International Life Extension Technology Workshop, Paris, France.

HEIJMAN, W., J.,M. \& HAGELAAR, G.,J.; \& VAN DER HEIDE C., M. 2019: Rural Resilience as a New Development Concept, EU Bioeconomy Economics and Policies

WILSON, G. 2010: Transactions of the Institute of British Geographers, New Series, Vol. 35, No. 3, $364-381$. https://doi.org/10.1111/j.1475-5661.2012.00516.x

HOLLING, C., S., 2001: Understanding the Complexity of Economic, Ecological, and Social Systems, Ecosystems, 4, 390-405.

HOLMES, J. 2017: The Smart Villages Initiative: Findings 2014-2017; The Smart Villages Initiative: Cambridge, UK,

IBRAHIM M. S. \& FAKHARU’L-RAZI, A. 2003: A review of disaster and crisis", Disaster Prevention andManagement, 12(1),24-32 http://dx.doi.org/10.1108/09653560310463829

KUTTOR, D. 2008: Creating Innovation Strategy in Bilateral Environment. Észak-Magyarországi Stratégiai Füzetek 4 69-77. 
NAGY, Y.,\& TÓTH, G., \& SZENDI, D., 2016: Opportunities for Adaptation of the Smart City Concept - A Regional Approach. Theory Methodology Practice: Club of Economics in Miskolc 12: Special Issue pp. 87-93. https://doi.org/10.18096/tmp.2016.02.08

NORTHSTREAM 2010: The revenue opportunity for mobile connected devices in saturated markets. Northstream White Paper. February 2010 ://northstream.se/ white-paper/archive (last accessed 12/01/2020)

OROSZ, D., \& PÉTER, ZS. 2018: Smart City Solutions in the Capitals of the EU Countries In: Urbančíková, N. (Ed.) Smart Communities Academy - The Proceeding of Papers and Presentations Košice, Slovakia: Technical University of Košice. pp. 45-58.

PÉTER, ZS., \& OROSZ, D. 2019: A megyei jogú városok útja az okos várossá válás folyamatában különös tekintettel a térinformatikai eszközök használatára (The Way of Cities with County Rights in the Process of Becoming a Smart City with Special Regard to the Use of GIS Tools) In: Kőszegi, I. R. (ed.) III. Gazdálkodás és Menedzsment Tudományos Konferencia III. Gazdálkodás és Menedzsment Tudományos Konferencia "Versenyképesség és innováció": Versenyképesség és innováció, Kecskemét, Hungary: Neumann János Egyetem, 673-679.

PRAUSE \& BOEVSKY 2015: Smart Rural Development, https://www.researchgate.net/publication/ 315655058_Smart_rural_development/download (12/01/2020)

SAYEGH, L., \& ANTHONY, W., P., \& PERREWÉ, P., L. 2004: Managerial decision-making under crisis. Human Resource Management Review, 14(2), 179-199. https://doi.org/10.1016/j.hrmr.2004.05.002

SZENDI, D. 2017: Települési jövedelmek térbeli kölcsönhatása: felzárkózás vs. tartós különbségek? (Spatial Interaction of Municipal Income: Catching Up vs. Lasting Differences?) In: Gelei, A. (Ed.) Sokszínủ gazdálkodástudomány: A 2016. év Tudomány Napja alkalmából szervezett PhD konferencia előadásai Budapest, Magyarország: MTA Gazdaság- és Jogtudományok Osztálya, pp. 141-174.

SU, K., \& LI, J., \& FU, H. 2011: Smart city and the applications. IEEE International Conference on Electronics, Communications and Control (ICECC), 1028-1031.

SZLÁVIK, J., \& CSÁFOR, H. \& SEBESTYÉNNÉ SZÉP, T. (2016) “Regional Level of Sustainability - Two Hungarian Case Studies”, Periodica Polytechnica Social and Management Sciences, 24(2), pp. $136-148$. https://doi.org/10.3311/PPso.7803.

https://iut.univ-amu.fr

http://okosvaros.lechnerkozpont.hu

https://sustainabledevelopment.un.org 